Jurnal Ilmu Ilmu Agribisnis: Journal of Agribusiness Science, 9(2), Mei 2021

\title{
ANALISIS KEUNGGULAN KOMPARATIF DAN KOMPETITIF USAHATANI UBI KAYU DI KECAMATAN BLAMBANGAN PAGAR KABUPATEN LAMPUNG UTARA
}

\author{
(Comparative and Competitive Advantages Analysis of Cassava Farming in Blambangan Pagar Sub- \\ district of North Lampung Regency)
}

\author{
Sayu Hadiyati Iswara, Raden Hanung Ismono, Muhammad Irfan Affandi
}

Jurusan Agribisnis, Fakultas Pertanian, Universitas Lampung, J1. Prof. Dr. Soemantri Brojonegoro No. 1 Bandar Lampung 35145, e-mail: hanung.ismono@fp.unila.ac.id

\begin{abstract}
This study aims to analyze the comparative and competitive advantages of two varieties of cassava, and determine the sensitivity due to changes in output prices, production volumes, and input prices to the comparative and competitive advantages of cassava farming in Blambangan Pagar Sub-district of North Lampung Regency. This research is a survey research involving 50 cassava farmers who were selected intentionally consisting of 25 farmers of Cassesart varieties and 25 farmers of Thailand varieties. To answer these objectives, the study uses PAM analysis (Policy Analysis Matrix). The results showed that Cassesart variety (UJ-5) cassava farming had a DRCR value of 0,15 and PCR of 0,46 so it was more competitive than Thailand variety (UJ-3) cassava farming which had a DRCR value Of 0,18 and PCR of 0,57. If there is a decrease in the output price for Cassesart variety (UJ-5) cassava by 4,93 percent and Thailand variety (UJ3) cassava by 5,32 percent, a decrease in production volume is 4,70 percent, and an increase in input prices (Urea fertilizer 21,32 percent, SP-36 fertilizer 34,40 percent, and NPK Phonska fertilizer 54,01 percent) due to the removal of fertilizer subsidies by the government, cassava farming is insensitive, therefore, despite changes in output prices, production volume, and the price of these inputs, cassava farming still has a competitive edge.
\end{abstract}

Keywords : cassava, comparative, competitive, PAM

\section{PENDAHULUAN}

Ubi kayu merupakan komoditas pangan strategis yang memiliki banyak manfaat karena selain sebagai bahan pangan pokok juga sebagai bahan baku industri. Menurut data FAO (2016), Indonesia merupakan negara penghasil ubi kayu terbesar ketiga di dunia. Indonesia juga mengimpor ubi kayu dari negara lain. Menurut data Kementerian Pertanian (2018), impor ubi kayu Indonesia jauh lebih besar dibandingkan ekspornya dan mengalami peningkatan volume impor sebesar 24,44 persen serta nilai impor sebesar 13,62 persen dari tahun sebelumnya. Hal ini menunjukkan bahwa produksi ubi kayu nasional tidak mampu memenuhi kebutuhan ubi kayu nasional, oleh karena itu, impor ubi kayu cenderung meningkat. Meningkatnya impor ubi kayu dapat merugikan Indonesia dan menyebabkan pemborosan devisa, oleh karena itu, pemerintah berupaya untuk meningkatkan keunggulan komparatif dan kompetitif usahatani ubi kayu.

Menurut Sambodo et al. (2007), keunggulan komparatif lebih menekankan pada sisi alokasi sumberdaya yang lebih efisien, sedangkan keunggulan kompetitif terkait erat dengan faktor penentu daya saing. Keunggulan komparatif dan kompetitif usahatani ubi kayu dapat dicapai melalui peningkatan produktivitas. Peningkatan produktivitas dapat dilakukan dengan mengalokasikan faktor-faktor produksi secara efisien untuk menghasilkan produksi yang maksimum atau dengan menekan biaya produksi.

Provinsi Lampung merupakan sentra komoditas ubi kayu di Indonesia dengan jumlah produksi sebesar 5.541.692 ton dan produktivitas sebesar 26,128 ton/ha (Kementerian Pertanian 2017). Kecamatan Blambangan Pagar merupakan salah satu sentra komoditas ubi kayu di Kabupaten Lampung Utara Provinsi Lampung dengan luas areal dan produksi ubi kayu terbesar sebesar 8.779 ha dan 204.366 ton. Meskipun luas areal dan produksi ubi kayu di Kecamatan Blambangan Pagar terbesar, namun produktivitas yang dihasilkan rendah bila dibandingkan dengan kecamatan lainnya yaitu sebesar 23,28 ton/ha (Dinas Pertanian Kabupaten Lampung Utara 2019). 
Produktivitas ubi kayu yang rendah diduga berkaitan dengan penggunaan input pada produksi ubi kayu yang masih belum optimal. Menurut Anggraini et al. (2013), rata-rata petani ubi kayu belum secara optimal dalam mengalokasikan faktor-faktor produksi dimana penggunaannya masih belum sesuai dengan yang dianjurkan. Oleh karena itu, produktivitas ubi kayu perlu ditingkatkan dengan mengalokasikan input produksi secara efisien sehingga usahatani yang dilakukan dapat menghasilkan produksi yang optimal.

Ubi kayu yang dihasilkan di Kecamatan Blambangan Pagar sebagian besar terdiri dari varietas unggul yaitu ubi kayu varietas Cassesart (UJ-5) dan ubi kayu varietas Thailand (UJ-3). Menurut Notowijoyo (2005), varietas unggul memiliki keunggulan produksi dan mutu hasil, peka terhadap pemupukan, toleran terhadap hama penyakit, umur genjah, tahan terhadap kerebahan, dan tahan terhadap cekaman lingkungan. Ubi kayu varietas Cassesart (UJ-5) menjadi salah satu varietas yang lebih disukai oleh petani untuk dibudidayakan karena memiliki keunggulan produktivitas tinggi dan memiliki kadar pati yang tinggi, sedangkan ubi kayu varietas Thailand (UJ3) banyak ditanam karena berumur pendek sekitar 8-10 bulan (Yuliadi 2018). Permasalahan lainnya yaitu petani ubi kayu yang mulai alih fungsi lahan ke tanaman lainnya seperti tanaman padi, jagung dan tanaman hortikultura yang dianggap lebih menguntungkan. Berdasarkan uraian diatas, maka penelitian ini bertujuan untuk mengetahui keunggulan komparatif dan kompetitif serta mengetahui kepekaan perubahan harga output, volume produksi, dan harga input terhadap keunggulan komparatif dan kompetitif usahatani ubi kayu.

\section{METODE PENELITIAN}

\section{Tempat dan Waktu Penelitian}

Penelitian ini dilakukan di Desa Pagar Gading dan Desa Tulung Singkip Kecamatan Blambangan Pagar Kabupaten Lampung Utara. Pengumpulan data dilaksanakan pada bulan Agustus-September 2019.

\section{Metode Penentuan Sampel}

Penelitian menggunakan metode survei. Pengambilan sampel menggunakan metode purposive sampling (Sugiyono 2016). Sampel berjumlah 50 orang, terdiri dari 25 petani ubi kayu varietas Cassesart (UJ-5) dan 25 petani ubi kayu varietas Thailand (UJ-3).

Tabel 1. Policy Analysis Matrix (PAM)

\begin{tabular}{|c|c|c|c|c|}
\hline & \multirow[b]{2}{*}{ Revenue } & \multicolumn{2}{|c|}{ Cost } & \multirow[b]{2}{*}{ Profit } \\
\hline & & $\begin{array}{c}\text { Input } \\
\text { Tradable }\end{array}$ & $\begin{array}{c}\text { Input } \\
\text { Non } \\
\text { Tradable }\end{array}$ & \\
\hline $\begin{array}{l}\text { Private } \\
\text { price }\end{array}$ & A & B & $\mathrm{C}$ & $\mathrm{D}$ \\
\hline $\begin{array}{l}\text { Social } \\
\text { price }\end{array}$ & $\mathrm{E}$ & $\mathrm{F}$ & $\mathrm{G}$ & $\mathrm{H}$ \\
\hline Divergence & I & $\mathrm{J}$ & $\mathrm{K}$ & $\mathrm{L}$ \\
\hline \multicolumn{5}{|c|}{ Sumber: Pearson et al. (2005) } \\
\hline \multicolumn{5}{|l|}{ Keterangan : } \\
\hline Keuntungan $\mathrm{Fi}$ & nsial & (D) & \multicolumn{2}{|c|}{$=\mathrm{A}-(\mathrm{B}+\mathrm{C})$} \\
\hline Keuntungan Ek & homi & (H) & \multicolumn{2}{|c|}{$=\mathrm{E}-(\mathrm{F}+\mathrm{G})$} \\
\hline Transfer Outpu & OT) & (I) & \multicolumn{2}{|c|}{$=\mathrm{A}-\mathrm{E}$} \\
\hline Transfer Input & adable (IT) & (J) & \multicolumn{2}{|c|}{$=\mathrm{B}-\mathrm{F}$} \\
\hline Transfer Input & ntradable (FT) & $(\mathrm{K})$ & \multicolumn{2}{|c|}{$=\mathrm{C}-\mathrm{G}$} \\
\hline Transfer Bersih & NT) & (L) & \multicolumn{2}{|c|}{$=\mathrm{I}-(\mathrm{K}+\mathrm{J})$} \\
\hline Rasio Biaya Pr & at (PCR) & & \multicolumn{2}{|c|}{$=\mathrm{C} /(\mathrm{A}-\mathrm{B})$} \\
\hline Rasio Biaya Su & berdaya Domest & tik (DRC) & \multicolumn{2}{|c|}{$=\mathrm{G} /(\mathrm{E}-\mathrm{F})$} \\
\hline Koefisien Prote & si Output Nomin & nal (NPCO) & \multicolumn{2}{|l|}{$=\mathrm{A} / \mathrm{E}$} \\
\hline Koefisien Prote & si Input Nominal & 1 (NPCI) & \multicolumn{2}{|l|}{$=\mathrm{B} / \mathrm{F}$} \\
\hline Koefisien Prote & si Efektif (EPC) & & \multicolumn{2}{|c|}{$=(\mathrm{A}-\mathrm{B}) /(\mathrm{E}-\mathrm{H})$} \\
\hline Koefisien Keun & Ingan (PC) & & \multicolumn{2}{|l|}{$=\mathrm{D} / \mathrm{H}$} \\
\hline Rasio Subsidi b & gi Produsen (SRI & & \multicolumn{2}{|l|}{$=\mathrm{L} / \mathrm{E}$} \\
\hline
\end{tabular}

\section{Jenis Data}

Jenis data yang digunakan dalam penelitian ini berupa data primer dan data sekunder. Data primer diperoleh melalui metode survei yaitu wawancara secara langsung kepada petani (responden) dengan menggunakan daftar pertanyaan (kuisioner) terbuka, sedangkan data sekunder diperoleh dari instansi-instansi dan beberapa literatur yang relevan terkait dengan tema penelitian.

\section{Metode Analisis dan Pengolahan Data}

Metode analisis yang digunakan dalam penelitian ini adalah Policy Analysis Matrix (PAM). Hal ini sejalan dengan penelitian sebelumnya Agustina (2008), Meliyana (2013), Septarisco (2019), Alghoziyah (2016), Ramanda (2016), Franiawati (2013), dan Andala (2014). Model PAM dapat dilihat pada Tabel 1. Pada penelitian ini, terdapat dua pengelompokan input yang dipakai oleh petani dalam berusahatani ubi kayu, yaitu input tradable dan input non tradable. Input tradable adalah input yang diperdagangkan di pasar internasional, sedangkan input non tradable adalah input yang tidak diperdagangkan di pasar internasional. Input tradable dalam penelitian ini adalah pupuk Urea, pupuk SP-36, pupuk NPK Phonska, pupuk KCl, dan pestisida. Input non tradable dalam usahatani ubi kayu meliputi bibit, peralatan, tenaga kerja, dan biaya lahan. Perhitungan biaya input tradable dan 
input non tradable dihitung berdasarkan harga privat dan harga sosial. Output dari usahatani ubi kayu merupakan komoditi yang diperdagangkan di pasar internasional.

\section{Analisis Sensitivitas}

Analisis sensitivitas dalam penelitian ini digunakan untuk mengetahui dampak perubahan nilai pada faktor-faktor produksi (input) dan output ubi kayu terhadap daya saing usahatani ubi kayu di Kecamatan Blambangan Pagar Kabupaten Lampung Utara. Alat analisis yang digunakan untuk mengukur sensitivitas yaitu elastisitas. Elastisitas yang digunakan dalam penelitian ini menurut konsep Haryono (1991) adalah elastisitas PCR dan DRCR. Secara matematis, rumusnya adalah :

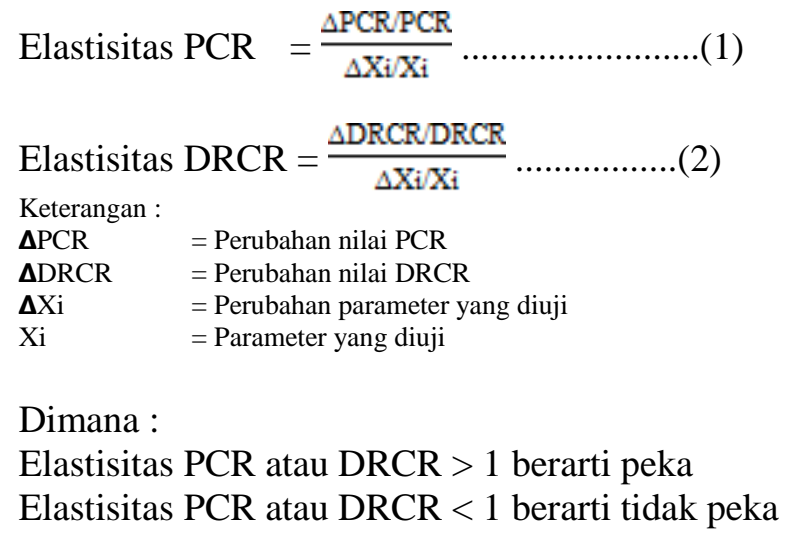

\section{HASIL DAN PEMBAHASAN}

\section{Karakteristik Responden}

Petani ubi kayu di Kecamatan Blambangan Pagar tergolong dalam usia produktif dengan kisaran umur 28 sampai 46 tahun yaitu sebesar 52 persen. Tingkat pendidikan formal petani responden bervariasi, mulai dari lulusan Sekolah Dasar (SD) hingga Sarjana (S1). Pendidikan petani mayoritas telah tamat Sekolah Menengah Atas (SMA) yaitu sebesar 38 persen. Tingkat pendidikan petani akan mempengaruhi dalam menyerap informasi, inovasi, teknologi, serta berpengaruh terhadap perilaku petani dalam mengelola usahatani.

Penguasaan lahan ubi kayu di Kecamatan Blambangan Pagar berkisar antara 0,5 sampai 2,5 hektar dengan rata-rata luas lahan petani sebesar 1,33 hektar dengan status kepemilikan lahan milik sendiri. Pengalaman berusahatani petani ubi kayu antara 5 sampai 55 tahun dengan rata-rata pengalaman petani lebih dari 24 tahun yaitu sebesar 30 persen, hal ini menunjukkan bahwa petani responden telah memiliki pengalaman yang cukup dan keterampilan yang memadai dalam

Tabel 2. Usahatani Ubi Kayu di Kecamatan Blambangan Pagar (per hektar)

\begin{tabular}{lrr}
\hline \multicolumn{1}{c}{ Uraian } & \multicolumn{1}{c}{ UJ-5 } & \multicolumn{1}{c}{ UJ-3 } \\
\hline $\begin{array}{l}\text { Kebutuhan Bibit } \\
\text { (batang) }\end{array}$ & $15.634,33$ & $16.151,52$ \\
Pupuk & & \\
Urea (kg) & 202,99 & 185,61 \\
SP-36 (kg) & 84,33 & 71,21 \\
NPK Phonska (kg) & 80,60 & 178,79 \\
KCl (kg) & 84,33 & 74,24 \\
Pestisida & & \\
Gramaxone (lt) & 1,76 & 1,91 \\
Paratop (lt) & 1,34 & 1,06 \\
Tenaga Kerja (HOK) & 78,40 & 77,19 \\
Penyusutan Alat (Rp) & $144.139,30$ & $149.606,06$ \\
Pajak Tanah (Rp) & $13.650,00$ & $13.650,00$ \\
Sewa Lahan (Rp) & $3.000 .000,00$ & $3.000 .000,00$ \\
Produksi (kg/ha) & $25.316,72$ & $21.458,48$ \\
Harga Ubi Kayu (Rp) & $1.306,60$ & $1.268,00$ \\
Penerimaan & $33.419 .056,72$ & $27.408 .472,73$ \\
Keuntungan & $19.529 .267,41$ & $13.246 .042,42$ \\
R/C & 2,41 & 1,94 \\
\hline
\end{tabular}

melakukan usahatani untuk mencapai hasil usahatani ubi kayu yang optimal. Semakin banyak dan lama pengalaman berusahatani, maka petani akan semakin terampil dalam melakukan usahataninya sehingga dapat digunakan untuk meningkatkan produksi dan mengurangi kegagalan dalam usahataninya.

\section{Keragaan Usahatani Ubi Kayu}

Usahatani ubi kayu di Kecamatan Blambangan Pagar diusahakan pada lahan kering. Waktu penanaman yang dilakukan oleh masing-masing petani tidaklah sama. Sebagian besar ubi kayu yang diusahakan oleh petani di Kecamatan Blambangan Pagar adalah ubi kayu varietas Cassesart (UJ-5) dan ubi kayu varietas Thailand (UJ-3). Rata-rata umur tanaman ubi kayu yang ditanam petani berkisar antara 8-12 bulan. Petani di Kecamatan Blambangan Pagar menanam ubi kayu sebanyak 2-3 kali dalam 2 tahun. Hal ini dikarenakan petani memiliki pertimbangan tertentu untuk melakukan panen lebih awal. Petani ubi kayu di Kecamatan Blambangan Pagar umumnya menjual hasil panennya kepada lapak ataupun pabrik. Rincian usahatani ubi kayu dapat dilihat pada Tabel 2.

\section{Penentuan Harga Privat dan Harga Sosial}

Harga privat adalah tingkat harga riil yang diterima petani dalam penjualan hasil produksinya atau tingkat harga yang dibayar petani dalam pembelian 
faktor produksi, sedangkan harga sosial adalah harga yang menggambarkan harga yang

Tabel 3. Harga privat dan sosial usahatani ubi kayu di Kecamatan Blambangan Pagar*

\begin{tabular}{lrr}
\hline \multicolumn{1}{c}{ Uraian } & Harga Privat & Harga Sosial \\
\hline Suku Bunga & $11,32 \%$ & $14,51 \%$ \\
Nilai Tukar & $14.246,00$ & $14.389,90$ \\
& $1.306,60$ & \\
Ubi Kayu & untuk UJ-5 & $3.958,87$ \\
& dan $1.268,00$ & \\
Kebutuhan Bibit & untuk UJ-3 & \\
(batang) & 348,00 & 348,00 \\
Pupuk & & \\
Urea (kg) & $1.800,00$ & $3.939,85$ \\
SP-36 (kg) & $2.000,00$ & $5.450,79$ \\
NPK Phonska (kg) & $2.300,00$ & $7.717,20$ \\
KCl (kg) & $5.800,00$ & $3.486,57$ \\
Pestisida & & \\
Gramaxone (lt) & $58.000,00$ & $46.400,00$ \\
Paratop (lt) & $47.000,00$ & $37.600,00$ \\
Tenaga Kerja (HOK) & $50.000,00$ & $50.000,00$ \\
& $144.139,30$ & $144.139,30$ \\
& untuk UJ-5 & untuk UJ-5 \\
Penyusutan Alat (Rp) & dan & dan \\
& $149.606,06$ & $149.606,06$ \\
& untuk UJ-3 & untuk UJ-3 \\
Biaya Lahan (Rp) & $5.000 .000,00$ & $5.000 .000,00$ \\
\hline * Lihat Lampiran & &
\end{tabular}

sesungguhnya yang seharusnya diterima petani baik harga input maupun output. Harga privat dan sosial usahatani ubi kayu di Kecamatan Blambangan Pagar Kabupaten Lampung Utara dapat dilihat pada Tabel 3.

\section{Analisis Keunggulan Komparatif dan Kompetitif Usahatani Ubi Kayu}

Matriks PAM usahatani ubi kayu di Kecamatan Blambangan Pagar Kabupaten Lampung Utara dapat dilihat pada Tabel 4. Tabel 4 menunjukkan bahwa secara keseluruhan usahatani ubi kayu varietas Cassesart (UJ-5) dan varietas Thailand (UJ-3) di Kecamatan Blambangan Pagar menguntungkan, hal ini dikarenakan memiliki nilai keuntungan finansial dan keuntungan ekonomi yang positif pada usahatani ubi kayu varietas Cassesart (UJ-5) sebesar Rp17.186.345,80 dan Rp83.399.386,14, dan pada usahatani ubi kayu varietas Thailand (UJ-3) sebesar Rp11.086.807,27 dan Rp67.421.314,72, sehingga dapat dikatakan usahatani ini layak untuk diusahakan baik secara finansial maupun ekonomi.

Keuntungan privat usahatani ubi kayu varietas Cassesart (UJ-5) lebih tinggi dibandingkan dengan keuntungan privat usahatani ubi kayu varietas Thailand (UJ-3). Tingginya keuntungan privat usahatani ubi kayu varietas Cassesart (UJ-5) dipengaruhi oleh tingginya penerimaan privat usahatani ubi kayu varietas Cassesart (UJ-5) yang dihasilkan petani. Penerimaan privat usahatani ubi kayu varietas Cassesart (UJ-5) yang tinggi disebabkan oleh kualitas dari ubi kayu yang lebih bagus dan lebih banyak berbuah (genjah) daripada ubi kayu varietas Thailand (UJ-3), namun usia panen untuk jenis ubi kayu varietas Cassesart (UJ5) lebih lama (Sari et al. 2018).

Keuntungan privat usahatani ubi kayu varietas Thailand (UJ-3) tergolong kecil, hal ini dikarenakan penerimaan privat usahatani ubi kayu varietas Thailand (UJ-3) relatif kecil. Salah satu penyebab rendahnya penerimaan privat usahatani ubi kayu varietas Thailand (UJ-3) adalah tingginya rafaksi. Menurut Yuliadi (2018), tingginya rafaksi (potongan timbangan) saat penjualan hasil di pabrik dikarenakan ubi kayu varietas Thailand (UJ3) memiliki kadar pati yang lebih rendah bila dibandingkan varietas Cassesart (UJ-5).

Nilai divergensi yang negatif pada usahatani ubi kayu varietas Cassesart (UJ-5) sebesar Rp66.213.040,34 dan pada usahatani ubi kayu varietas Thailand (UJ-3) sebesar Rp56.334.507,45, artinya adanya distorsi pasar atau kegagalan pasar dimana pembeli menguasai harga pasar (monopsoni) yang menyebabkan kebijakan atau campur tangan pemerintah tidak memberikan kontribusi yang efektif terhadap penerimaan yang

Tabel 4. PAM usahatani ubi kayu di Kecamatan Blambangan Pagar

\begin{tabular}{lrrrr}
\hline \multicolumn{1}{c}{ Description } & \multicolumn{1}{c}{ Revenue } & Input Tradable & Input Non Tradable & Profit \\
\hline Varietas Cassesart (UJ-5) & & & & \\
Private & $33.078 .821,67$ & $1.373 .791,04$ & $14.518 .684,82$ & $17.186 .345,80$ \\
Social & $100.225 .683,74$ & $2.307 .612,78$ & $14.518 .684,82$ & $83.399 .386,14$ \\
Divergences & $-67.146 .862,07$ & $-933.821,73$ & - & $-66.213 .040,34$ \\
\hline Varietas Thailand (UJ-3) & & & & \\
Private & $27.209 .358,79$ & $1.478 .909,09$ & $14.643 .642,42$ & $11.086 .807,27$ \\
Social & $84.951 .432,11$ & $2.886 .474,97$ & $14.643 .642,42$ & $67.421 .314,72$
\end{tabular}


$-57.742 .073,32$

Tabel 5. Nilai DRCR dan PCR usahatani ubi kayu di Kecamatan Blambangan Pagar

\begin{tabular}{ccc}
\hline Varietas & DRCR & PCR \\
\hline Varietas Cassesart (UJ-5) & 0,15 & 0,46 \\
Varietas Thailand (UJ-3) & 0,18 & 0,57 \\
\hline
\end{tabular}

didapatkan petani ubi kayu, dan sebaliknya apabila bernilai positif berarti kebijakan pemerintah telah mampu memberikan kontribusi yang efektif terhadap penerimaan dan pengeluaran dalam usahatani tersebut, oleh karena itu, pemerintah harus lebih memperhatikan kebijakan harga baik input maupun output yang mampu memberikan kontribusi yang lebih efektif.

Usahatani dianggap berdaya saing jika memiliki keunggulan komparatif dan kompetitif. Keunggulan komparatif dalam analisis PAM diukur dengan DRCR (Domestic Resource Cost Ratio) sedangkan keunggulan kompetitif diukur dengan PCR (Private Cost Ratio). Nilai DRCR dan PCR usahatani ubi kayu disajikan pada Tabel 5. Tabel 5 menunjukkan bahwa nilai DRCR usahatani ubi kayu varietas Cassesart (UJ-5) dan usahatani ubi kayu varietas Thailand (UJ-3) masing-masing sebesar 0,15 dan 0,18 atau lebih kecil dari satu (DRCR < 1). Hal ini berarti bahwa untuk memperoleh nilai tambah sebesar Rp100 diperlukan input non tradable (faktor domestik) sebesar Rp15 dan Rp18. Nilai DRCR tersebut menunjukkan bahwa usahatani ubi kayu varietas Cassesart (UJ-5) dan usahatani ubi kayu varietas Thailand (UJ-3) memiliki keunggulan komparatif dan produsen mampu memproduksi satu unit nilai tambah dengan faktor domestik yang lebih rendah. Nilai DRCR usahatani ubi kayu varietas Cassesart (UJ-5) sebesar 0,15 lebih kecil bila dibandingkan dengan nilai DRCR usahatani ubi kayu varietas Thailand (UJ-3) sebesar 0,18, yang berarti bahwa usahatani ubi kayu varietas Cassesart (UJ-5) memiliki keunggulan komparatif yang lebih tinggi dibandingkan dengan usahatani ubi kayu varietas Thailand (UJ-3).

Tabel 5 juga menunjukkan bahwa nilai PCR usahatani ubi kayu varietas Cassesart (UJ-5) dan usahatani ubi kayu varietas Thailand (UJ-3) masing-masing sebesar 0,46 dan 0,57 atau lebih kecil dari satu $(\mathrm{PCR}<1)$. Hal ini berarti bahwa untuk memperoleh nilai tambah sebesar Rp100, maka besar biaya input non tradable (faktor domestik) yang harus dikeluarkan oleh petani sebesar Rp46 dan Rp57. Nilai PCR tersebut menunjukkan bahwa usahatani ubi kayu varietas
$-1.407 .565,88$

$-56.334 .507,45$

Cassesart (UJ-5) dan usahatani ubi kayu varietas Thailand (UJ-3) memiliki keunggulan kompetitif dan mampu membiayai faktor domestiknya pada harga privat. Nilai PCR usahatani ubi kayu varietas Cassesart (UJ-5) sebesar 0,46 lebih kecil bila dibandingkan dengan nilai PCR usahatani ubi kayu varietas Thailand (UJ-3) sebesar 0,57, yang berarti bahwa usahatani ubi kayu varietas Cassesart (UJ-5) memiliki keunggulan kompetitif yang lebih tinggi dibandingkan dengan usahatani ubi kayu varietas Thailand (UJ-3).

\section{Analisis Sensitivitas}

Skenario yang digunakan dalam analisis sensitivitas pada penelitian ini adalah skenario gabungan dari penurunan harga output, penurunan volume produksi, dan bila subsidi input dicabut pemerintah. Pada penelitian ini dilakukan skenario penurunan harga output pada ubi kayu varietas Cassesart (UJ-5) sebesar 4,93 persen dan pada ubi kayu varietas Thailand (UJ-3) sebesar 5,32 persen. Hal ini dikarenakan harga ubi kayu varietas Cassesart (UJ-5) di lokasi penelitian mencapai kisaran Rp1.306,60/kg dan ubi kayu varietas Thailand (UJ-3) mencapai kisaran Rp1.268,00/kg, sedangkan harga ubi kayu terendah selama sepuluh tahun terakhir berada dikisaran Rp1.800/kg. Skenario juga dilakukan untuk volume produksi dikarenakan volume produksi ubi kayu mengalami penurunan sebesar 4,7 persen pada tahun 2012 . Selain itu, skenario juga dilakukan pada subsidi input pupuk apabila dicabut oleh pemerintah, maka terjadi kenaikan harga pupuk Urea sebesar 21,32 persen, pupuk SP-36 sebesar 34,40 persen, dan pupuk NPK Phonska sebesar 54,01 persen. Analisis sensitivitas usahatani ubi kayu varietas Cassesart (UJ-5) dan varietas Thailand (UJ-3) di Kecamatan Blambangan Pagar disajikan pada Tabel 6.

Tabel 6 menunjukkan bahwa perubahan harga output, volume produksi, dan harga pupuk menyebabkan nilai PCR meningkat dari 0,46 menjadi 0,53. Hal ini berarti perubahan harga output, volume produksi, dan harga pupuk tersebut akan menyebabkan tingkat keunggulan kompetitif yang semakin berkurang. Nilai elastisitas PCR usahatani ubi kayu varietas Cassesart (UJ-5) di Kecamatan Blambangan Pagar bernilai kurang dari satu yaitu berkisar antara 0,00 sampai 0,03 . Hal ini menunjukkan bahwa usahatani ubi kayu varietas Cassesart (UJ-5) di Kecamatan Blambangan Pagar tidak peka terhadap perubahan harga output, volume produksi, dan harga pupuk. Tabel 6 juga 
Tabel 6. Analisis sensitivitas usahatani ubi kayu varietas Cassesart (UJ-5) dan ubi kayu varietas Thailand (UJ-3) di Kecamatan Blambangan Pagar, 2019

\begin{tabular}{lcccc}
\hline \multirow{2}{*}{ Uraian } & \multicolumn{3}{c}{ UJ-5 } & UJ-3 \\
\cline { 2 - 5 } & PCR & Elastisitas PCR & PCR & Elastisitas PCR \\
\hline Nilai Awal & 0,46 & & 0,57 & \\
Penurunan Harga Ubi Kayu & 0,53 & 0,03 & 0,68 & 0,04 \\
Penurunan Produksi Ubi Kayu & 0,53 & 0,03 & 0,68 & 0,04 \\
Kenaikan Harga Pupuk Urea & 0,53 & 0,01 & 0,68 & 0,01 \\
Kenaikan Harga Pupuk SP-36 & 0,53 & 0,00 & 0,68 & 0,01 \\
Kenaikan Harga Pupuk NPK Phonska & \multicolumn{1}{c}{0,53} & 0,00 & 0,68 & 0,00 \\
\hline \multicolumn{1}{c}{ Uraian } & \multicolumn{3}{c}{ UJ-5 } \\
\cline { 2 - 5 } & DRCR & Elastisitas DRCR & DRCR & Elastisitas DRCR \\
\hline Nilai Awal & 0,15 & & 0,18 & \\
Penurunan Produksi Ubi Kayu & 0,16 & 0,01 & 0,19 & 0,01 \\
\hline
\end{tabular}

menunjukkan bahwa perubahan harga output, volume produksi, dan harga pupuk menyebabkan nilai PCR meningkat dari 0,57 menjadi 0,68 . Hal ini berarti perubahan harga output, volume produksi, dan harga pupuk tersebut akan menyebabkan tingkat keunggulan kompetitif yang semakin berkurang. Nilai elastisitas PCR usahatani ubi kayu varietas Thailand (UJ-3) di Kecamatan Blambangan Pagar bernilai kurang dari satu yaitu berkisar antara 0,00 sampai 0,04. Hal ini menunjukkan bahwa usahatani ubi kayu varietas Thailand (UJ-3) di Kecamatan Blambangan Pagar tidak peka terhadap perubahan harga output, volume produksi, dan harga pupuk.

Tabel 6 menunjukkan bahwa perubahan volume produksi menyebabkan nilai DRCR meningkat dari 0,15 menjadi 0,16. Hal ini berarti perubahan volume produksi tersebut akan menyebabkan tingkat keunggulan komparatif yang semakin berkurang. Nilai elastisitas DRCR usahatani ubi kayu varietas Cassesart (UJ-5) di Kecamatan Blambangan Pagar bernilai kurang dari satu yaitu 0,01. Hal ini menunjukkan bahwa usahatani ubi kayu varietas Cassesart (UJ-5) di Kecamatan Blambangan Pagar tidak peka terhadap perubahan volume produksi. Tabel 6 juga menunjukkan bahwa perubahan volume produksi menyebabkan nilai DRCR meningkat dari 0,18 menjadi 0,19 . Hal ini berarti perubahan volume produksi tersebut akan menyebabkan tingkat keunggulan komparatif yang semakin berkurang. Nilai elastisitas DRCR usahatani ubi kayu varietas Thailand (UJ-3) di Kecamatan Blambangan Pagar bernilai kurang dari satu yaitu 0,01. Hal ini menunjukkan bahwa usahatani ubi kayu varietas Thailand (UJ-3) di Kecamatan Blambangan Pagar tidak peka terhadap perubahan volume produksi.

\section{KESIMPULAN}

Berdasarkan penelitian yang dilakukan dapat disimpulkan bahwa usahatani ubi kayu varietas Cassesart (UJ-5) di Kecamatan Blambangan Pagar memiliki keunggulan komparatif dan kompetitif yang lebih tinggi dibandingkan usahatani ubi kayu varietas Thailand (UJ-3) di Kecamatan Blambangan Pagar. Apabila terjadi penurunan harga output untuk ubi kayu varietas Cassesart (UJ-5) sebesar 4,93 persen dan ubi kayu varietas Thailand (UJ-3) sebesar 5,32 persen, penurunan volume produksi sebesar 4,70 persen, serta peningkatan harga input (pupuk Urea sebesar 21,32 persen, pupuk SP-36 sebesar 34,40 persen, dan pupuk NPK Phonska sebesar 54,01 persen) akibat pencabutan subsidi pupuk oleh pemerintah, maka usahatani ubi kayu tidak sensitif, dengan demikian, walaupun terjadi perubahan harga output, volume produksi, dan harga input tersebut, usahatani ubi kayu tetap memiliki daya saing.

\section{DAFTAR PUSTAKA}

Agustina T. 2008. Analisis daya saing apel tropis di Kota Batu. J-SEP, 2(2): 23-31. https://jurnal.unej.ac.id/index.php/JSEP/article /view/422. [6 Januari 2019].

Alghoziyah, Ismono RH, Sayekti WD. 2016. Daya saing usahatani karet rakyat di Desa Kembang Tanjung Kecamatan Abung Selatan Kabupaten Lampung Utara. Jurnal Ilmu Ilmu Agribisnis, 4(3): 243-252. http://jurnal.fp.unila.ac.id/index.php/JIA/articl e/view/1498. [24 Juni 2020].

Andala A, Abidin Z, Situmorang S. 2014. Keunggulan kompetitif dan komparatif usahatani manggis di Kabupaten Tanggamus. Jurnal Ilmu Ilmu Agribisnis, 2(3): 214-221. http://jurnal.fp.unila.ac.id/index.php/JIA/articl e/view/803. [4 Januari 2019]. 
Anggraini N, Hasyim AI, Situmorang S. 2013. Analisis efisiensi pemasaran ubi kayu di Provinsi Lampung. Jurnal Ilmu Ilmu Agribisnis, 1(1): 80-86.

http://jurnal.fp.unila.ac.id/index.php/JIA/articl e/view/135/139. [4 Januari 2019].

BPS [Badan Pusat Statistik]. 2018. Realisasi Penerimaan Negara (Milyar Rupiah), 20072019.

http://www.bps.go.id/statictable/2009/02/24/1

286/realisasi-pendapatan-negara-milyar-

rupiah-2007-2019. [5 September 2019]. 2019. Statistik

Indonesia 2019. Badan Pusat Statistik. Jakarta. Hlm. 1-738.

BI [Bank Indonesia]. 2019. Tingkat Inflasi, Suku Bunga, dan Nilai Tukar Uang Periode 2018. http://www.bi.go.id. [5 September 2019].

Dinas Pertanian Kabupaten Lampung Utara. 2019. Program Penyelenggaraan Penyuluhan Pertanian Kabupaten Lampung Utara Tahun 2019. Dinas Pertanian Kabupaten Lampung Utara. Kotabumi.

FAO [Food and Agriculture Organization]. 2016. Food Outlook : Biannual Report on Global Markets. FAO. Roma.

Franiawati CI, Zakaria WA, dan Kalsum U. 2013. Daya saing jagung di Kecamatan Sekampung Udik Kabupaten Lampung Timur. Jurnal Ilmu Ilmu Agribisnis, 1(4): 291-297. http://jurnal.fp.unila.ac.id/index.php/JIA/articl e/view/703/645. [5 Januari 2019].

Gittinger JP. 1986. Analisa Ekonomi ProyekProyek Pertanian. Edisi ke 2. Diterjemahkan oleh : Slamet Sutomo dan Komet Mangiri. UI Press. Jakarta.

Haryono D. 1991. Keunggulan Komparatif dan Dampak Kebijakan pada Produksi Kedelai, Jagung, dan Ubi Kayu di Provinsi Lampung. Tesis. Institut Pertanian Bogor. Bogor.

Kementerian Pertanian. 2017. Statistik Pertanian 2017. Pusat Data dan Sistem Informasi Pertanian Kementerian Pertanian Republik Indonesia. Jakarta. Hlm. 1-362.

2018. Statistik Makro

Sektor Pertanian 2018. Pusat Data dan Sistem Informasi Pertanian Kementerian Pertanian. Jakarta. Hlm. 1-114.

Meliyana R, Zakaria WA, Nurmayasari I. 2013. Daya saing lada hitam di Kecamatan Abung Tinggi Kabupaten Lampung Utara. Jurnal
Ilmu Ilmu Agribisnis, 1(4): 271-277. http://jurnal.fp.unila.ac.id/index.php/JIA/articl e/view/702/644. [5 Januari 2019].

Notowijoyo SIT. 2005. Kamus Pertanian. CV Aneka Ilmu. Semarang.

Putri JP, Suhartini, Hanani N. 2019. Comparative and competitive advantages analysis of cassava case in Simalungun District North Sumatera Province Indonesia. AGRISE, 19(1): 9-18.

https://agrise.ub.ac.id/index.php/agrise/article/ view/302. [4 September 2019].

Ramanda E, Hasyim AI, Lestari DAH. 2016. Analisis daya saing dan mutu kopi di Kecamatan Sumberjaya Kabupaten Lampung Selatan. Jurnal Ilmu Ilmu Agribisnis, 4(3): 253-261.

http://jurnal.fp.unila.ac.id/index.php/JIA/articl e/view/1499/1353. [24 Juni 2020].

Sari ZL, Suwarni N, Utami D. 2018. Usaha pertanian ubi kayu di Desa Gaya Baru III Kecamatan Seputih Surabaya Lampung Tengah. Jurnal Penelitian Geografi, 6(5): 115.

http://jurnal.fkip.unila.ac.id/index.php/jpg/arti cle/view/16381. [24 Juni 2020].

Septarisco YKNJ dan Prihtanti TM. 2019. Daya saing usahatani padi di Kecamatan Susukan Kabupaten Semarang Menggunakan Metode PAM (Policy Analysis Matrix). AGRINECA, 19(1): 1-15.

http://ejournal.utp.ac.id/index.php/AFP/article /view/814. [5 Februari 2019].

Sugiyono. 2016. Metode Penelitian Kuantitatif, Kualitatif, dan $R \& D$. Alfabeta. Bandung.

Sukmaya SG, Rachmina D, Saptana. 2016. Analisis daya saing dan dampak kebijakan pemerintah terhadap komoditas kedelai vs pengusahaan kedelai di Kabupaten Lamongan Jawa Timur. Forum Agribisnis, 6(1): 21-46. http://journal.ipb.ac.id/index.php/fagb/article/ view/17230. [3 September 2019].

Winarno ST dan Darsono. 2019. Ekonomi Kopi Rakyat Robusta di Jawa Timur. Uwais Inspirasi Indonesia. Ponorogo.

Yuliadi E. 2018. Beberapa Varietas atau Klon Cassava. Lembaga Penelitian dan Pengabdian pada Masyarakat Universitas Lampung-Badan Penelitian dan Pengembangan Daerah Lampung Tengah. Lampung. 


\section{Jurnal Ilmu Ilmu Agribisnis: Journal of Agribusiness Science, 9(2), Mei 2021}

* Keterangan :

1) Nilai tukar mata uang

Nilai tukar mata uang privat adalah nilai tukar rata-rata pada tahun 2018, yaitu sebesar Rp14.246,00/US\$ (BI 2019). Nilai ekspor rata-rata pada tahun 2018 adalah Rp2.812.037.850.000.000,00, sedangkan nilai impor rata-rata pada tahun 2018 adalah Rp2.689.709.410.000.000,00. Penerimaan negara dari pajak ekspor rata-rata pada tahun 2018 adalah Rp3.000.000.000.000,00, sedangkan penerimaan negara dari pajak impor rata-rata pada tahun 2018 adalah Rp35.700.000.000.000,00 (BPS 2018). Berdasarkan hasil perhitungan, diperoleh angka konversi baku (SCF) tahun 2018 sebesar 0,99 sehingga harga sosial nilai tukar mata uang (SER) adalah Rp14.389,90/US\$.

2) Output

Harga privat ubi kayu adalah harga ubi kayu yang diterima petani pada waktu menjual hasil panen di daerah penelitian sebesar Rp1.306,60/kg pada varietas Cassesart (UJ-5) dan Rp1.268,00/kg pada varietas Thailand (UJ-3), sedangkan harga sosial ubi kayu sebesar Rp3.943,47/kg. Harga sosial tersebut didapat dari nilai CIF (Cost, Insurance and Freight) ubi kayu US\$ 0,26/kg (BPS 2019). Harga CIF ubi kayu dikalikan dengan harga sosial nilai tukar mata uang, yaitu Rp14.330,67, sehingga menjadi Rp3.725,97/kg, kemudian ditambah dengan biaya tataniaga yang berupa biaya bongkar muat $\mathrm{Rp} 55,00 / \mathrm{kg}$, biaya transportasi ke provinsi Rp100,00/kg. Hasil tersebut kemudian dikurangi dengan biaya distribusi tingkat petani sebesar Rp62,50/kg, sehingga diperoleh harga sosial ubi kayu sebesar Rp3.943,47/kg.

3) Bibit

Harga privat bibit ubi kayu sebesar Rp348,00/batang stek. Menurut Sukmaya, Rachmina, dan Saptana (2016), penentuan harga sosial bibit ubi kayu didekati dari harga privatnya karena pengadaannya berasal dari dalam negeri serta tidak adanya distorsi baik karena distorsi kebijakan pemerintah maupun distorsi pasar.

4) Pupuk

Harga privat pupuk adalah harga yang dibayarkan petani dalam memperoleh pupuk, sedangkan penentuan harga sosial pupuk Urea, SP-36, NPK Phonska, dan $\mathrm{KCl}$ diperoleh dari nilai FOB/CIF yang sudah dikonversi dalam mata uang domestik ditambah biaya bongkar muat, gudang, transportasi, dan biaya distribusi ditingkat petani. Harga privat dan harga sosial pupuk usahatani ubi kayu dilihat pada Tabel 7.
Tabel 7. Harga privat dan sosial pupuk pada usahatani ubi kayu

\begin{tabular}{lrr}
\hline \multicolumn{1}{c}{ Pupuk } & Harga Privat (Rp) & Harga Sosial (Rp) \\
\hline Urea & $1.800,00$ & $3.939,85$ \\
SP-36 & $2.000,00$ & $5.450,79$ \\
NPK Phonska & $2.300,00$ & $7.717,20$ \\
KCl & $5.800,00$ & $3.486,57$ \\
\hline
\end{tabular}

5) Pestisida

Menurut Sukmaya, Rachmina, dan Saptana (2016), penentuan harga sosial pestisida didekati dengan harga privat pada lokasi penelitian, kemudian dikurangi tarif impor sebesar 10 persen dan pajak pertambahan nilai sebesar 10 persen.

6) Peralatan

Harga privat peralatan pertanian merupakan harga peralatan yang dibayarkan petani dalam memperoleh peralatan. Menurut Winarno dan Darsono (2019), penentuan harga sosial peralatan usahatani dihitung berdasarkan nilai penyusutan per tahun yang dinilai sama dengan harga privatnya. Hal tersebut karena tidak adanya subsidi atau pajak yang dikenakan pada peralatan pertanian yang digunakan.

7) Tenaga Kerja

Harga privat tenaga kerja adalah harga upah tenaga kerja di daerah penelitian, yaitu sebesar Rp50.000,00/HOK. Menurut Putri, Suhartini, dan Hanani (2019), harga sosial tenaga kerja dihitung dengan menggunakan nilai upah privat yang berlaku di lokasi penelitian. Hal ini karena kebutuhan tenaga kerja dalam kegiatan pertanian dapat dipenuhi oleh masyarakat setempat dengan menggunakan tenaga manusia dan sewa alat pertanian (tenaga mesin) berupa traktor.

8) Lahan

Harga privat lahan yang digunakan adalah harga lahan yang dibeli oleh petani yaitu sebesar Rp5.000.000/ha. Menurut Gittinger (1986), penentuan harga bayangan lahan dapat berupa nilai sewa aktual, harga beli maupun berupa pendapatan dari tanah untuk tanaman alternatif terbaik. Pada penelitian ini harga sosial lahan yang digunakan adalah harga beli lahan pada saat awal pembelian pada tahun 1992, sehingga harga sosial lahan sama dengan harga privatnya. 